\title{
複文解析と文法的思考 \\ 一中・上級日本語教育への体系機能的アプローチー \\ Clause complex analysis and thinking grammatically: \\ Systemic functional approach to intermediate and advanced \\ Japanese language teaching
}

照屋一博

香港理工大学

\section{要旨}

本稿は、中・上級レベルの日本語学習者の学習ジャーナルを用いて、意味づくりの 資源として機能する文法とその学習の過程を例示するものである。ここでは、修辞的 な言語論理を構築するために主語や主題などの機能が体系的に複文に統合される複文 化 clause complexing の意味・論理構造に焦点をあてることで、「文法的に思考する」 ことが学習者の言語についての認識を高め、究極的には、複雑な複文構造の生成と処 理を助けるだけではなく、それがディスコースの学習への突破口となることを提示寸 る。

キーワード :

複文、文法的な思考、論理・意味的な関係、言語能力、意味の潜在性 


\section{複文解析と文法的思考}

一中・上級日本語教育への体系機能的アプローチー 1

\section{照屋一博 \\ 香港理エ大学}

\section{1. はじめに}

言語学習は、意味づくりの過程とその産物であるテクスト、あるいはディスコース の学習を意味している (Halliday，1993；Matthiessen，2006）。そういった意味では、 学習の対象となる言語が第 1 言語の母語であれ、第 2 言語あるいは外国語（以下、ま とめて外国語）としての言語であれ、本質的にかわりはない。

言語を用いた意味づくりは、読み、書き、聞き、話しという異なるモードを必要に 応じて活用しながら、ある特定の文化や状況のコンテクストにおける意味の総体を、 ある特定の言いまわしを使って具現することを話し手に要求する。文化・社会コンテ クストにおける意味の具現のし方はさまざまだが、外国語教育においては、その特殊 性（日常性や専門性）あるいはその語彙文法的な難易度によって、言語学習の全過程 をいくつかのレベルに分類し、学習の対象として取り扱う。ここでいう言語学習にお ける全過程とは、言語話者としての個体がおこなう言語理解と言語生成が開始、発達、 そして老年によって衰退・消失していくその過程を意味し、言語教育の場においては、 言語能力試験や言語教育のカリキュラムにみる初級、中級、上級と呼ばれるレベルを 総体的にさしている。

本稿では、外国語教育における日本語能力の中級から上級レベルへの移行に必要な 言語の具現性に着眼し、言語に内在する「複雑性」、特に複文化 clause complexing について論ずる。具体的には、日本語能力試験のN1 レベルの認定の目安としてあげ られている「複雑な文章や抽象度の高い文章などを読んで、文章の構成や内容を理解 することができる」2という「認定の目安」における「複雑な文章」の「理解」と呼ば れるものが、具体的にはどういった言語能力を要求しているのかということを論ずる ものである。

\section{2. 静的な文法と動的な文法}

先に、母語の学習も外国語の学習も意味づくりの学習であるという点では同じだと 述べた。しかし、実際には、ある言語 A からある言語 B へ意味を言いかえるというこ とは、言うまでもなく、一筋縄ではいかない難しさを内包している。ひとつには、異

\footnotetext{
1 本研究は、香港理工大学人文学部の研究費補助金（1-ZVB4）を部分的に受け実現したものである。

2 http://www. jlpt.jp/about/levelsummary.html。(2014 年 9 月 20 日)
} 
なる文化・状況のコンテクストに適した言語 A の言いまわし、あるいは目標言語 B に は存在しないコンテクストで生成される意味までをも、言語 B で表現しなくてはなら ない、話し手の能力に左右される難しさがある。それと同時に、言語自体の違いを理 解しないことには、適切に意味を具現できないという言語体系がもつ差異に由来する 難しさも存在している。Lantolf（2006）を用いて、後者の指す難しさについて例をあ げよう。前者については、本稿の論外であるため、別の機会に言及したい。つぎの例 は、動作を表現する出来事の連鎖が英語とスペイン語では異なるし方で表現された例 である（記号「||」は文の境界を示す）。

(1) As I painted the ceiling, || paint spots progressed across the floor. （天井にペンキを塗っていると、||ペンキのシミが床を流れ出した）

(2) Mientras pintaba el techo, || iban cayendo manchas de pintura por todo el suelo || e iban formando progresivamente una hilera

(As I painted the ceiling, || drops of paint were falling on the floor || and they have progressively formed a line、天井にペンキを塗っている と、ペンキが床に落ちて、次第に線を作った）。

ここで、Lantolf は、彼が提唱する言語と文化の一体化「languaculture 言文化」を 描写するが、それと同時に言語の語彙体系的違いを示唆している。たとえば、英語で は、ふたつの文で構成される複文 (1) が、スペイン語では、連結された 2 つ文では 事象が同様に描写できないため、3つの独立した動作からなる複文に言いかえなけれ ばならない。つまり、経験の断片の言語化が両言語では異なっている。

日本語もそれにもれず、たとえば、日本語における複文（言語語記述文法研究会、 2008、宮島・仁田、1995）の複雑さをもたらす論理的秩序は、以下で述べるように、 英語やスペイン語のようなゲルマン民族語のそれとは異なっている。複文の学習とは、 この論理的秩序の学習に他ならない。

ここでいう複文の論理的秩序は、第 5 章で述べるように、相補関係にある「概括的 synoptic」な視点と「動的 dynamic」な視点をもちいて解釈することができる。つま り、概括的な視点から複文という現象を静止した存在物として捉え、動的な視点から ダイナミックに連鎖する出来事として捉える。たとえば、言語は、語彙として辞書に 記録・編纂される現象であると同時に、スポーツ中継のように継起する出来事の伝達 を可能にする現象でもある。複文の相補的な性質は、固定された存在物として、そし て流動的な動きとして映し出される。

複文の学習で問題となるのは、このような言語の相補的な側面が言語使用者や言語 学習者には可視できない操作であることである。概括的に構築される語彙としての単 
語は、区切りがある程度明白であり、個別に検索が可能であるなど、可視的であるの に対し、動的に構築される文法は、一般的であり、潜在的であるため、不可視である。 つまり、文法を「構文」として静的物体の一覧として教えられ、文脈を剥奪された伝 統的なドリル練習によって培われた学習者の知覚では(Byrnes，2006：18）、文法は、 不可視な存在でしかありえない。不可視なものは、対象化されず、学習の対象とはな らない。

このような視点の欠如は、言語を物体、あるいは規則の束として扱う言語教育を優 勢にさせてきた。具体的には、複文の生成や処理における言語能力の発達、全般的に は、言語学習者個人の「意味の潜在性 meaning potential」の発達 (Matthiessen, 2006) を妨げている。

以下では、視点の欠如がもたらす学習上の障害を乗り越える解決策として、体系機 能言語学的なアプローチを、言語学習者の学習ジャーナルを例にとりながら紹介す る。解決策は、相補的な視点から捉えられる複文の指導方法でもあるが、究極的には、 その新しい言語視野から学習者が得る洞察力が文法的な思考を可能にし、学習能力を 培うという、学習者の発見である。

\section{3. 複文の文法と論理の動き}

静的な側面だけでなく、文法の動的な側面を見せることで洞察力を養うためには、 まず、既成概念の変革からはじめなければならない。たとえば、文法のコースの始め に学生が綴った学習ジャーナルの例をみてみよう。以下にはコースの学習目的につい ての困惑が浮き出ている。

「このコースを終わる頃には、辞書さえあればどんなテキストでも読めるよう になると先生がいったが、［中略］ジャンルやテキストに実際に使われている 文体や文法を学習しないで、すべてのタイプのテキストが読めるようになるは ずがない。でも、このコースでは、日本語のコミュニケーションコースでやっ たように、文法の使い方を勉強するのではなく、意味づくりのためにテキスト を分析し、文章を論理的な部分に分けるらしい。（翻訳、筆者）」

3 オーストラリアの大学で開講された、初級後半から中級レベルの学生を対象にした日本語文法の 科目で学生が 14 週間英語で記した学習の記録。指導学習と自律学習のふた項目を枠組みに綴ら れた。以下で「翻訳」とあるのはすべて学生の学習ジャーナルからの引用である。 
学生の困惑の帰結を例示する前に、まず体系機能的な観点から言語、特に文法を特 徵づけておこう（Halliday，1978, Halliday \& Matthiessen, 2013）。言語は、文化・ 社会のコンテクストで機能する。そういった環境にある言語に内在する文法は、以下 のように特徵づけをうける。

(1) 文法は、意味づくりの資源である。

(2) 文法は、自然言語の処理体系であり、異なるタイプの意味を創出する。文法は、 正確にいうと語彙文法であり、文法と語彙を内包した単一の連続体である。

(3) 文法は、人間の経験を創出する理論であり、人間相互の役割や関係を演じさせ、 意義化された現実あるいは仮想の世界を意味のまとまりとして創出する。

(4) 文法は、主語や主題という文法機能によって、異なる意味を文に一体化する。複 文の範疇においては、意味的論理を構築する。

以下では、上記の文法の特徵を視野にいれながら、連結された複文の文法範疇を意 味・論理的に解析し例示する。ここでとりあげる意味・論理関係は、〈時間〉と〈原 因·条件〉で、後者の〈原因·条件〉は、4つの主要な意味・論理型の一つで、通常、 条件と結果という二つの構成要素から成り立っている（詳細は Teruya, 2007）。複文 の意味・論理関係は、相補的な $3 つ の$ 観点「上」「下」「まわり」からの観察が可能 である。〈条件〉を例にとって見てみよう。

「上から」見るということは、調査の対象である〈条件〉を意味内容として捉える ことを意味し、「下から」見ることは、〈条件〉の表現面を調査すること、そして「周 り」から見るということは、〈条件〉の置かれた環境、この場合は〈条件〉と関連す るその他の意味・論理関係との関連をみることをそれぞれ意味する。ある観点から見 た場合、同一にみえるものが、他の観点からは異なって見えたり、その逆であったり もする。このように調査対象をホリスティックに観察するアプローチのことを、体系 機能言語学では、「a trinocular perspective（三眼的遠近立体法）」と呼んでいる (Halliday \& Matthiessen, 1999: 504)。

たとえば、つぎのふたつの複文（3）と（4）を「下から」観察すると、〈条件〉 が「［した］ら」といら同一の構造接続詞（あるいは、従属的接続詞）によって連結 されていることがわかる。

（3）［ $\beta:]$ 彼の住所がわかっていたら、 $[\alpha:]$ 彼に手紙を出しただろう。

(4) $[\beta:]$ 私だったら、 $[\alpha:]$ 彼女に真実を教えただろう。 
しかし、逆に「上から」、つまり意味の観点からみた場合、二つの複文の意味内容 が異なっていることが判然とする。例文（3）は、実際に起こらなかった出来事を描 いている。事実に相反する出来事を使って、実際に起こったこととは逆の出来事を連 鎖させた例で、「彼の住所がわからなかったので、彼に手紙を出せなかった」という 意味を表している。それとは異なり、例文（4）は、仮想上の出来事を表現している。 つまり、この場合「真実を教える」ということは現実化しない出来事として映し出さ れている。

それとは異なり、「まわりから」見た場合、つまり、「［した］ら」で具現される 論理・意味関係をパラディグマティック paradigmatic に観察した場合、それが〈条 件〉という環境のもとで、たとえば「雨が降ったら、僕は出かけない」のような〈潜 在性〉と相関関係にあることが明らかになってくる（詳細は、Teruya，2009を参照）。

このように意味内容は異なっているのに対し、先に述べたように、「下から」見た 場合、同じ構造接続詞「［した］ら」が使われていることしか見えてこない。日本語 は、現実と非現実の表現のし方だけではなく、複文の連結のし方も英語のような言語 とは異なっている。その点を分析を通して明らかにしよう。

先の例（3）と（4）を、連結された 2 つ文の相互依存関係の観点から分析する と、いずれも「 $\beta$ ` $\alpha\rfloor^{4}$ となる。つまり、両者は、一方の従属する文 $\beta$ が後続する 独立文 $\alpha$ に依存して連結したハイポタクティックな構造 hypotactic structure（伝 統的な文法では、従属 subordination）からなる。ここでは、ハイポタクティックな 構造を便宜上、そして学習者が教室でそうしていたように、単に「ハイポ」と呼ぶ。 日本語の場合、中核となる情報を内包した独立文（主文）は、複文構造の終わりに位 置する。

それとは対照的に、連結された文が等位関係にあるばあい、たとえば「まず大阪へ 行き、そして沖縄へ行った」のように連結される文が同等の地位をもち、一方が他方 に依存することなく独立して存在するばあいは、パラタクティックな関係となる。同 様に、略して「パラ」な関係と呼ぶ。

英語は、ハイポな複文の構造が基本的に日本語とは異なる。簡単にいうと、英語の ばあい、日本語と同じように $\beta$ ^ $\alpha$ となることもあるが、その逆の連結 $\alpha$ ‘ $\beta$ も可能 である。日本語の場合、 $\alpha \hat{} \beta$ は基本的に存在しない。いいかえると、他に文法的に

4 パラタクティックな構造は、数字の表記（1、2、3 等）を用い、「1^2」と表記し、ここで 用いたギリシャ小文字表記（ $\alpha, \beta, \gamma$ 等）は、連結された文が同等ではないこと、そして「」」 記号は「に続く」を示している。 
特別な理由がない限り、日本語は、出来事の連鎖を逆進的な配置（ $\beta$ ^ $\alpha)$ の中に捉え ることで論理が後退的であるのに対し、英語のような言語は、連鎖が前進的であり、 よって論理が進行的である。

このように複文を特徵づけると、学習者の注意が喚起される。

「英語では、重要なメッセージをどこに置くかは、それが始め（前進的論理） であっても、終わり（逆進的論理）であってもあまり関係がないが、日本語は、 ほとんどの場合、逆進的な論理になっている。だから、日本人と話をする場合、 要点を把握するためには、文の最後まで注意深く聞かなければならない。」（翻 訳、筆者)

文法に内在するこのような言語的な違いを認知することは（Byrnes，2006：16）、 論理の学習を可能にする。しかし、このような認知は、文法を明晰に活用できること が前提となる。複文化の学習についていうと、複文を「下から」みることで構造接続 詞を孤立させて教えるのではなく、関連する主語や主題などの文法機能との関係でホ リスティックにアプローチする必要がある。そのためには、複数個の文が連結した複 文にまで学習の範囲を広げる必要がある。それが学習の突破口となって、意味づくり を助長する。例をみてみよう。

\section{4. 意味づくりにおける文法機能と相互関係}

以下の例は、旅行代理店における海外旅行計画の会話からの抜粋である。会話が展 開する状況のコンテクストは、旅行についての客の問い合わせに対して、旅行代理人 が情報を提供することで、旅行に関する一連の行動を可能にしようとするものである。

旅行代理人 $[\mathrm{A}]$ と客 $[\mathrm{B}]$ との間には、立場上、上下関係、そして社会的な力関係 に違いが存在する。その対人関係が敬語の使用に反映している。以下、 $[\mathrm{a}]-[\mathrm{d}]$ は、述 語動詞をさす。

（5） [A] ええ、事前に [a：］お申し込みいただければ、はい、予約を [b: $]$ お取 りいたしますので。

（6） [B] じや、もうちょっと [c:］検討して、また $[\mathrm{d}:]$ 参ります。

5 『RWCP 音声データベース 音声対話データベース（RWCP-SP96）』 
構造的にみると、 [A] と [B] の複文には、いずれも主語が明示されていない。し かし、意味上、主語が存在していることは、つまり、述語に表現された意味の担い手 がはっきりしていることは、非明示でも会話がなりたっていることに明らかである （Teruya，2004）。具体的には、「尊敬」を示す述語 $[\mathrm{a}]$ が、主語が「聞き手=相手」 であることを暗示し、「謙遜」を表現する $[\mathrm{b}]$ と $[\mathrm{d}]$ は、「話し手＝本人」が主語で あることを示している。［c］の場合、テ形であるため、論理・意味的に、ふたつの出 来事が時間的に継起していること、そして後続する述語 $[\mathrm{d}]$ 一の従属を意味している。 このようにテ系で連結された複文は、そのほとんどが同一の主語を共有していて（言 語学研究会、1989）、一方の主語の同定が他方の同定へとつながっていく。

日本語における「主語の機能」の学習（そして教授）がむずかしいのは、このよう な主語の非明示性にある。しかし、主語の認定に実践で使用されるのは、「が」「は」

「の」などの後置詞である。非明示な日本語の主語を、明示的な後置詞で捉えられる のだろうか。このような「下から」の文法的アプローチは、表現上目に見えない意味 内容を顕示できないという点において不十分である。

主語を視界にいれながら、今度は、複文の論理構造における〈主題〉の機能をみて みよう。表 1 は、小説からの抜粋で、出来事を再現するタイプのテクストである。左 から 2 番目のコラムは、先に説明したパラ・ハイポな関係をあらわすタクシス taxis な関係で、タクシスな関係は、通常複文の意味的な境界を示す。パラな独立文（［c]） が意味的な境をあらわし、ハイポな非独立文（［a］など）が、述語の意味が後続する 文に依存しながら継続していることを示す。 3 番目のコラムに意味・論理構造の概括 的な分析を示した。 4 番目のコラムは、その論理構造内における〈主題 Theme〉、そ して 5 番目のコラムは、主題を述べ立てる、通常、新情報として機能するレーマ Rheme である。

表 1 :複文の概括的な論理構造

\begin{tabular}{|c|c|c|c|c|c|c|}
\hline 文 & タクシス & \multicolumn{3}{|c|}{ 概括的な論理構造 } & 主題／ & レーマ \\
\hline a & ハイポ & \multirow[t]{3}{*}{$1+$} & \multirow[t]{2}{*}{$\beta \times$} & $\beta \times$ & 私は & 2 杯目のオンザロックを飲みほしてから \\
\hline b & ハイポ & & & $\alpha$ & & ベッドルームに行って \\
\hline c & パラ & & \multicolumn{2}{|l|}{$\alpha$} & & 電話帳を調べ、 \\
\hline $\mathrm{d}$ & ハイポ & \multirow[t]{3}{*}{2} & \multicolumn{2}{|l|}{$\beta \times$} & & 図書館に電話をかけて、 \\
\hline $\mathrm{e}$ & パラ & & \multirow[t]{2}{*}{$\alpha$} & $1 ”$ & & 「レファレンスの係の方を」と \\
\hline $\mathrm{f}$ & - & & & 2 & & 言った \\
\hline
\end{tabular}


ここでいう〈主題〉とは、特定の解釈へと読者を導くようにテクストを結束させる テクスト機能のうちの一つである。日本語の主題は、典型的に後置詞「は」でハイラ イトされる。表 1 の複文には、5つの文からなる複文の始めの文にだけ〈主題〉が現 れていて、このばあい、主題と主語が合体している。一般的に言って、複文における 主題は、複文の冒頭か、その近辺に出現するが、複文が展開する途中で主題の変更が 必要な場合、または、主題の意味的な継続が弱いところに出没する。さもなければ、 主題は、非明示の形をとることで、意味の継続性をあらわす（主題の継続性について は、Givón, 1983 を参照）。

この機能的性質に加え、複文の論理·意味的 logico-semantic な連結関係が主題の解 明の手がかりとなる。紙面の都合上、詳しくは触れられないが、あとで必要になって くる「増強 enhancing」にのみ述べ、同レベルの他タイプ「敷衍」「拡張」について は割愛する。「増強」は、一方が他方を飾り立てる（「[ $\left.\beta^{\times}:\right]$部屋に入ったら、 $[\alpha:]$ めまいがした」） 6

さらにそれらとはタイプが異なる「投射 projection」がある。伝統的に言う引用と 同じだが、先の例文の [e] のような「発言」だけではなく、「アイデア」を含む点で 引用とは異なる。前者を「“」、後者を「‘」で示す。

複文における主題の継続性を、内包されたふたつのミクロな連結、そして全体的な 枠組みとなるマクロな連結の順で解析しよう。

たとえば、表 1 の「(b)ベッドルームに行って、（c) 電話帳を調べ」は、先にみたテ 形を従えているため、主題を共有している。2つの出来事間の論理·意味的な連鎖が「時 間的進行」を実現していて、「ベッドルームに行く」というテ形で印されている。こ の先行するハイポな出来事が偶発的に発生し、それに支配される形で（c）の「電話帳 を調べる」という出来事が発生する。このことは、複文の（b）と（c）のふたつの文の 主語が同一であることを示している。

同じ解釈が動詞のテ形で複合された $\beta$ （「(d)図書館に電話をかけて」）に後続す る $\alpha$ (「(e)レファレンスの係りの方を」と（「(f)言った」）にもあてはまる。 は、テ形であるため先の例と同じ理由で、後続文の主語と同一であることを示してい る。（e）と（f)の連結は、（e)が (f)によって言動的に投射された話し手の発言（直接引 用)であるため、主題はそこで断続している?

6 分析記号は「×」を用い、先に紹介したタクシス関係に付記して、論理・意味関係を表す (Halliday

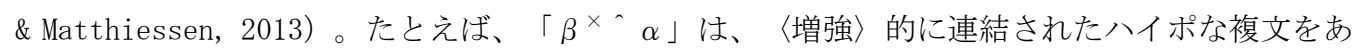
らわす。

7 出来事を〈再現〉するタイプのテクストは、小説のように、会話の部分と地の部分から構成され て物語が展開するが、両者は、異なる次元でストーリーを展開させる。そういった意味で、地の 文の登場人物が投射した発言の中の主題は、地の文の主題とは個別に展開していく。 
複文全体は、3つの文がそれぞれ連結してふたつのマクロな出来事を構成し、並列 している。記号でしめすと、1(a+b+c)^2(d+e + f) となる。

先行する $1(\mathrm{a}+\mathrm{b}+\mathrm{c})$ は、3つの文が時間の継起によって従属的に連結し、後続す る $2(\mathrm{~d}+\mathrm{e}+\mathrm{f})$ は、1つ目の出来事「電話をかけて」に発言が継起している。この 1 と 2 のマクロな出来事自体は、パラな関係を示すマス形の述語をもつ(c)「電話帳を 調べ」によって連結されている。このようにマス形で連結された複文は、テ形の場合 とは異なり、先行文と後続文の主語が同一である確率が同じであるため、それだけで は主語を断定できないが、電話を調べる主体と電話をかける主体が同一であることが わかる。

このような文法的な解釈は、複文の構造の根底にある意味・論理的な秩序を意識化 させ、学習者は、そうすることで、文法的に思考するようになる（Teruya，2006）。 この文法的な思考は、学習者を啓発し、さらに言語学習のストラテジーを認識させる 触媒として働く（Swain，2006 を参照）。学習者は、文法的な思考を獲得できると、 明白 overt な構造要素のあるなしに影響されることなく、省略のように目には見えな い, covert な操作（Worf，1956：70）を解釈する足場を得ることができるようになる。

\section{5. 複文化一複文の追跡と復元}

これまでは、複文が概括的に、つまり「読む」ようなし方で分析できることをみて きた。この概括的な理解は、意識的に意味を処理する言語学習を助成するが、それは、 10 歳ごろまでの子供が言葉を無意識にそして容易に習得する第一言語学習 （Halliday，1986/2007，p. 209）とは異なる。外国語を理解する過程を意識化するこ とは、具体的には、複文の論理の認識を助け、その認識を学習ストラテジーとして機 能させる。

以下の（7）は、解析のし方を説明する学習者が綴った理解を示す例である。学習 者は、複文を解体し理解するにあたって、潜在的な文法の仕組みを意識的に用いて、 複文「（a）月が欠け、（b）また月が満ちても、（c）男達は、帰ってこなかった」を正 確に理解している。

（７）（a）は進行のタイプでパラ。（b）は却下のタイプだからハイポ。最初に (a) のパラタクティックを見た時、(a) と（b）で切ったが、それぞれの主語を 調べたら気が変わった。（a）と（b）は主語が同じで、（c）は異なっている。よ って、（b）と（c）で切って、（a）と（b）をひとつのまとまりとした。結果は、 $\beta=\left(1^{\times}\right.$^ 2$) \wedge \alpha$ となる。 
ここに映し出されているのは、学習者が複文を概括的に解析することで、自分なり の理解を発見していることである。複文を概括的に考えることは、動的な理解を助長 する。それは、「意味の行為」（Halliday，1992）としての言語の動的な側面（ある いは、Swain 2006 の言う「languaging（言語化）」）の把握を意味する。話すことと 聞くことに特に顕著な動的な意味の展開を解読する新たな理解と洞察力が得られるか らである。

表 2 は、中級レベルの日本語学習者がおこなった複文の解析とその注釈を復元した ものである。ここで学習者は、学習あるいは認識の発達における二つの様式、つまり

「行為」と「理解」（Edelman \& Tononi，2000：15-16）の観点から相補的に複文を解 析している。このような解析は、先にみた三眼的遠近立体的視点なくしては得られな い。

左にある最初の太線で囲まれた分析は、発話の順序を段階的に追った描写で、発話 を継起する「行為」としてとらえている。そして右端にある二番目の分析は、構築さ れた論理の統合のされ方を描いたもので、論理的な「理解」を描いている。ここで大 切なのは、複文が直線的な時間にそって個別に展開しながら、論理的な全体に統合さ れていることである。

言語学習者は、実際のコミュニケーションの場で、このようなふたつの様式で意味 をほぼ同時にリアルタイムで理解・生成しなければならない。それは、話し手が今何 を話しているのか聞きとろうとすると同時に、その次に何を言おうか思考を回らすそ の時間と苦労に似ている。このような学習者の意識は、話し言葉と書き言葉を合成さ せ、言語能力を助長する。

表 2 : 複文の動的かつ概括的な分析 ${ }^{8}$

\begin{tabular}{|l|l|l|l|l|l|l|l|}
\hline 彼の店では夕方になると & 条件:実際:結果 & $\beta^{\times}$ & & $\gamma^{\times}$ & & & \\
\hline \\
その日の一日で売れ残った \\
野菜を集めて、
\end{tabular}

8 分析によって得られた複文の理解が以下の学習者の英訳にあらわれている。「When it became the bothersome evening at his shop he gathered vegetables that were not sold each and every day and then rewrote the prices as "how much a pile" and then had put them out at the storefront. 」

論文 
一境界が「なると」で印された最初の文は、繰り返し起こる習慣的な出来事のよ うなので、〈即時〉系のチャンスによる発生というよりも、〈当然の結果として の事実〉だ。その次の文の境界は、テ形の「集める」だから、〈時間的な進行〉 系で、この文が最初の依存関係を印している。それからここの「野菜」を形容す る埋め込み文は、中立するテンスを示しているから記述的な埋め込み文だ。

一次の文の境界は、様態系の「ように」でできていて、值段が書き直されている 様子を指定しているから、この動詞「変えて」はまた〈時間的な進行〉系だ。

- 2 番目の文の境界「集めて」は特定の時間で、それに続く〈時間的な進行〉を 探すと、 4 番目の文の境界「変えて」にあるから、これでこの二つの出来事が進 行しながらメインの文まで連結しているだけでなく、グループ関係を示している ことがわかる。（翻訳、筆者）

これは、文法的な思考のほんの一例に過ぎない。日本語能力試験の認定レベルでい うと、N 3 レベルの学習者が取り組んだ読解の試みではあるが、「複雑な文章」という レベルでは、そして「文章の構成や内容を理解する」という観点では、おそらく N 3 以上のレベルといっても過言ではないだろう。実際、文章の複雑さのひとつの基準で ある複文化の観点から能力試験をみると、N 1 レベルの試験項目以外には、3つ以上の 文で構成された複文例は、あまりみうけられない。

本稿で例示した、学習ストラテジーとしての文法的な思考は、能力試験のいかんに かかわらず、外国語のリテラシーの発達、特に、複文化のもつ複雑性の処理を少なく とも可能にする。それは、学習者自身が言語の原理を意識的に理解でき、意図的に操 作できるようになるという点で優れている。このことは、非漢字圈の学習者が常に対 面する語彙理解をも支援してくれる。1 4 週間の指導学習後における、つぎのような 学生の内省がそれを裏付けている。

文とその下層にある意味と文法との関係について得た経験、洞察力と理解は、 確かに自分の言語能力のレベルを超えたテクストを読む能力を高めてくれた。 一字一句理解しなくても、ほとんどのテクストにアクセスできるということは、 屈辱的な敗北感ではなく、むしろ開放感を味わわせてくれる。これからは、自 然言語のテキストの読解は、やりがいのある面白いパズルだ。（翻訳、筆者） 


\section{6. おわりに}

言語学習は、その言語のおかれた文化と状況のコンテクストにおける意味の潜在性 を学ぶことにある。本稿では、学習者の個人化された意味の潜在性がどのように発達 寸るのかを、概括的で動的な性質をもつ複文化を範疇にとらえ、体系機能的に例示し た。複文に具現する言語の複雑性を効果的に習得する効果的なストラテジーとして、 言語の文法的な仕組みについての認識のレベルを意識的にあげる「文法的な思考」に ついて述べた。具体的には、概括的な複文と動的な複文の複雑さをもたらす論理構造 を解析し、それらを相補的に合成できる程度の文法的な思考をもつことが、学習者の 自律学習を可能にし、高次のリテラシーへ導く。

本稿で述べた複文化の理解と生成の視覚的な論理・意味的な解析は、意味づくりの 認識を培う。たとえば、構造接続詞の「［し］たら」という形態素を単独で意味的に 〈条件〉と関連づける従来の教え方よりも、その解析が他の関連する文法機能を多角 的に活用するという点で優れている。さらに、意味と文法を機能的に活用する文法的 な思考は、ディスコースへの突破口として働く。

紙面の都合上、詳しくは説明できないが、日本語の場合、複文を連結する構造接続 詞の機能的な認識は、接続詞の修辞的な機能の理解へと直接つながっていく。たとえ ば、上記の構造接続詞「［し］たら」が具現する複文の論理・意味的な関係が認識で きれば、それと形態論的に相似する接続詞「としたら」の、ディスコースにおける修 辞的な役割、つまり、部分を全体につなげる接続詞の機能が認識できるようになる。 それは、「［し］たら」の前後の文の関係と、「としたら」の前後の文脈とを比較す ることで、ディスコース構造が理解できるからである。いいかえると、複文化の文法 的な仕組みの認識を学習者に培うことができれば、ディスコースへの関門へと学習者 を導き、それを突破させる能力をあたえることは、そうむずかしいことではない。こ れまで孤立して存在していた構造の断片が、学習者にとっては、形態論的に、そして 修辞論的につじつまがあうような機能的な存在になるからで、ディスコースにアクセ スできるようになるということは、目標言語における意味の理解と創造の豊かさへの 解放を意味寸るからである。 


\section{複文解析と文法的思考 \\ 一中・上級日本語教育への体系機能的アプローチー}

\section{参考文献}

言語研究会構文論グループ（1989）「なかどめ：動詞の第一なかどめのばあい」言語学研究会編『こ とばの科学 2 』麦書房 pp. 163-179

宮島達夫、仁田義雄（編）（1995）『日本語類語表現の文法（下）複文・連文編』くろしお出版

日本語記述文法研究会（編）（2008）『現代日本語文法 6-第 11 部 複文』くろしお出版

照屋一博 (2013) 「報道における投射文のもつ言語論理」Proceedings of JASFL，Vol. 6. 113-124.

Byrnes, H. (2006). What kind of resource is language and why does it matter for advanced language learning?: An introduction. In H. Byrnes (ed.), Advanced language learning: The contribution of Halliday and Vygotsky. London: Continuum, pp. 1-28.

Edelman, M. G., \& Tononi, G. (2000). Consciousness: How matter becomes imagination. London: The Penguin Press.

Givón, T. (ed.) (1983), Topic continuity in discourse: A quantitative cross-language study. Amsterdam/Philadelphia: Benjamins.

Halliday, M. A. K. (1978). Language as social semiotic: The social interpretation of language and meaning. London: Edward Arnold.

Halliday, M. A. K. (1986/2007). Learning Asian languages. University of Sydney Centre for Asian Studies, 1986 25, (2). Reprinted in M. A. K. Halliday (2007), Language and education. J. J. Webster (ed.) London: Continuum, pp. 194-213.

Halliday, M. A. K. (1992). The act of meaning. In J. E. Alatis (ed.), Language, communication and social meaning, Georgetown University round table on languages and linguistics. Washington, DC: Georgetown University Press, pp. 7-21.

Halliday, M. A. K. (1993). Towards a language-based theory of learning. Linguistics and Education, 5, 93-116.

Halliday, M. A. K., \& Matthiessen, C. M. I. M. (1999). Construing experience through meaning: A language-based approach to cognition. London: Cassell.

Halliday, M. A. K., \& Matthiessen, C. M. I. M. (2013). An introduction to functional grammar (4 ${ }^{\text {th }}$ edition). London: Edward Arnold.

Lantolf, J. P. (2006). Re(de)fining language proficiency in light of the concept of 'languaculture'. In H. Byrnes (ed.), Advanced language learning: The contribution of Halliday and Vygotsky. London: Continuum, pp. 72-91.

Matthiessen, C. M. I. M. (2006). Educating for advanced foreign language capacities: Exploring the meaning-making resources of languages systemic-functionally. In H. Byrnes (ed.), Advanced language learning: The contribution of Halliday and Vygotsky. London: Continuum, pp. 31-57.

Swain, M. (2006). Language, agency and collaboration in advanced second language proficiency. In H. Byrnes (Ed.), Advanced language learning: The contribution of Halliday and Vygotsky. London: Continuum, pp. 95-108.

Teruya, K. (2004). Metafunctional profile of the grammar of Japanese. In A. Caffarel, J. R. Martin, \& C. M. I. M. Matthiessen (eds.), Language typology: A functional perspective. Amsterdam/Philadelphia: Benjamins, pp. 184-254.

Teruya, K. (2006). Grammar as a resource for the construction of language logic for advanced language learning in Japanese. In H. Byrnes (ed.), Advanced language learning: The contribution of Halliday and Vygotsky. London: Continuum, pp. 109-133.

Teruya, K. (2007). A systemic functional grammar of Japanese. Two volumes. London: Continuum. Whorf, B. L. (1956). Language, thought and reality. Cambridge, MA: The MIT Press. 